\title{
REIVINDICAR EL PASADO PARA TRANSFORMAR EL PRESENTE Y LEGITIMAR LA REVOLUCIÓN CONSTITUCIONAL: HISTORICISMO Y DIPUTADOS CATALANES EN LAS CORTES DE CÁDIZ
}

\author{
RECLAIMING THE PAST TO TRANSFORM THE PRESENT \\ AND LEGITIMIZE THE CONSTITUTIONAL REVOLUTION: \\ HISTORICISM AND CATALAN DEPUTIES IN THE SPANISH \\ PARLIAMENT OF CADIZ
}

\author{
Antoni Sánchez Carcelén \\ Universidad de Lleida
}

Entregado el 16-5-2014 y aceptado el 11-3-2015.

Resumen: Durante el proceso constituyente gaditano la tradición constitucional medieval se erigió en un extraordinario recurso para legitimar el inmovilismo absolutista o, por el contrario, para validar la tarea legislativa de signo liberal, ya que la cultura constitucional de 1812 fue, además de católica, profundamente historicista. En buena medida porque en las continuas apelaciones de los diputados catalanes más destacados - de hecho, Capmany, Aner, Espiga, Dou y Creus fueron los únicos que se manifestaron al respecto de una manera significativa - a la historia de la Corona de Aragón, a la antigua constitución de la monarquía española y a las leyes fundamentales castellanas cabían tanto las propuestas serviles como las reformistas.

Palabras clave: Cortes de Cádiz, Constitución de 1812, diputados catalanes, historicismo, liberalismo y absolutismo.

Abstract: During the constituent from Cadiz process the constitutional medieval tradition was raised in an extraordinary resource to legitimize the absolutist immobility or, on the contrary, to validate the legislative task of liberal 
sign, since the constitutional culture of 1812 was, besides catholic, deeply historicist. Largely because the continuous appeals of the leading Catalan deputies - indeed, Capmany, Aner, Espiga, Dou and Creus were the only ones to respect a meaningful way demonstrated - to the history of the Crown of Aragon, to the former constitution of the Spanish monarchy and to the fundamental Castilian laws there were fitting both the servile offers and the reformists.

Key words: Spanish Parliament of Cadiz, Constitution of 1812, Catalan deputies, historicism, liberalism and absolutist. 


\section{El historicismo del Congreso gaditano}

El interés por la historia de España se acrecentó durante el reinado de Felipe V. El primer monarca de la dinastía Borbón fundó la Real Academia de la Historia el 18 de abril de 1738 «para purificar y limpiar la [historia] de nuestra España de las fábulas que la deslucen e ilustrarla de las que parezcan más provechosas». ${ }^{1}$ Además, a medida que avanzó el siglo XVIII, se incrementó paulatinamente el despertar de la consciencia histórica y nacional. ${ }^{2}$ Leer y escribir Historia ${ }^{3}$ se convirtió en una práctica habitual entre ensayistas, prosistas, dramaturgos, letrados, burócratas, funcionarios, investigadores, eruditos y notables que integraban la República de las Letras ${ }^{4}$ con vocación de intervención pública. Aspecto nada baladí, ya que, de hecho, constituyó un componente fundamental en la elaboración del discurso nacional que acompañó tanto la consolidación del régimen borbónico como la fundación de la nación liberal. ${ }^{5}$ Asimismo, en tiempos de Carlos IV las lecturas de la historia tuvieron una vocación pedagógica-política por su crítica al despotismo. ${ }^{6}$

En los territorios de la antigua Corona de Aragón también se revitalizó el interés por la historia. Por ejemplo, en Cataluña, los estudios históricos fueron promovidos por la Academia de Buenas Letras y, poste-

1 Joaquín Varela Suanzes-Carpegna, «Nación, representación y articulación territorial del estado en las Cortes de Cádiz», en Pedro Rújula (Coord.), Dossier Constitución y representación en las Cortes de Cádiz. Los diputados aragoneses, Jerónimo Zurita, 87, 2012, p. 11.

2 Antonio Morales Moya, «Estado y Nación en la España contemporánea», Ayer, 37, 2000, pp. 233-270.

3 José Antonio Maravall, «Mentalidad burguesa e idea de la Historia en el Siglo XVIII», Revista de Occidente, T. XXXVI, 107, 1972, pp. 250-286.

4 Javier Fernández Sebastián, «De la «República de las letras» a la «opinión pública»: intelectuales y política en España (1700-1814)», en DD.AA., Historia, filosofía y política en la Europa moderna y contemporánea, Universidad de León, León, 2004, pp. 13-40.

5 José María Portillo Valdés, «Imaginación y representación de la Nación española. (El debate sobre la naturaleza de la representación nacional y la tentativa de Francisco Xavier Uriortua)», Anuario de Historia del Derecho español, 65, 1995, pp. 267-320; y Carmen García Monerris, «Lectores de Historia y hacedores de política en tiempos de fractura “constitucional"», Historia Constitucional, 3, 2002, pp. 39-98, http://hc.rediris.es/03/index. html.

${ }^{6}$ María Cruz Romeo Mateo, «Nuestra antigua legislación constitucional, ¿modelo para los liberales de 1808-1814?», en Pedro Rújula y Jordi Canal (Eds.), Guerra de Ideas. Política y cultura, Marcial Pons, Madrid, 2011, p. 88. 
riormente, por la Sociedad Filosófica y Literaria. ${ }^{7}$ El historicismo, en su concepción general del mundo que sitúa la historia (y el supuesto destino histórico) en el centro de la vida política, había surgido como una reacción frente a la razón y la Ilustración más humanista, con la pretensión de poder deducir de la historia el método específico de estudio de la sociedad para extraer normas supuestamente científicas y reglas morales válidas para el presente. ${ }^{8}$

Así pues, el legado institucional y cultural del pasado adquirió una evidente función política para legitimar tanto el nuevo modelo político emanado de la Guerra de Sucesión como los diferentes posicionamientos ideológicos hegemónicos a principios del siglo XIX. Precisamente, fue en las Cortes de Cádiz donde la interpretación del pasado sirvió para justificar o, por el contrario, refutar las múltiples y diversas iniciativas legislativas: «en la lucha que mantienen los revolucionarios contra los conservadores la tradición presta sus armas a todos por igual. Los mismos textos utilizados por autores de ideologías distintas sirven como argumentos para probar posiciones radicalmente enfrentadas». ${ }^{9}$ Los liberales, para evitar la identificación de sus propuestas con las provenidas de la Francia revolucionaria, por temor a ser tildados de afrancesados o de traidores, equipararon las novedades reformistas con la simple prolongación de las medievales libertades castellanas o aragonesas. Por tanto, nada sustancial era nuevo, todo procedía, depurado y organizado, de la experiencia constitucional propia, ya que únicamente se trataba de la transformación en un texto de tipo legal de reglas, principios y soluciones de gobierno y administración existentes. Mientras que, los conservadores moderados -inspirados en el sistema parlamentario británico $-{ }^{10}$, para legitimar la instauración de un régimen constitucional, alegaron la estricta recuperación de las

${ }^{7}$ Mireia Campabadal i Bertran, La Reial Acadèmia de Bones Lletres de Barcelona en el segle XVIII. L'interès per la història, la llengua i la literatura catalanes, Publicacions de l'Abadia de Montserrat, Barcelona, 2006.

8 Friedrich Meinecke, El Historicismo y su génesis, Fondo de cultura económica, México, 1943; y Fluvio Tessitore, Interpretación del historicismo, Anthropos, Barcelona, 2007.

9 Miguel Artola, Los orígenes de la España Contemporánea, Instituto de Estudios Políticos, Madrid, 1959, T. I, pp. 282-283.

10 Joaquín Varela Suanzes-Carpegna, «Los modelos constitucionales en las Cortes de Cádiz», en François-Xavier Guerra (Dir.), Revoluciones Hispánicas, Independencias Americanas y Liberalismo Español, Universidad Complutense, Madrid, 1995, pp. 243268. 
antiguas leyes fundamentales ${ }^{11} ; \mathrm{y}$, finalmente, los serviles ${ }^{12}$ o reaccionarios evocaron a Clío para, por ejemplo, salvaguardar la soberanía real de derecho divino, la sociedad estamental basada en el privilegio o el régimen señorial. Así que, las razones históricas solamente constituyeron un lugar común desde el que construir y proyectar los argumentos políticos. ${ }^{13}$

El Congreso gaditano ${ }^{14}$ se convirtió en un espacio de negociación historicista, protagonizado, en buena medida, por unos diputados catalanes ${ }^{15}$ que ya contaban con una dilatada experiencia. Por ejemplo, el filólogo, archivero e historiador Antonio de Capmany de la Junta de Ceremonial - auxiliar de la Junta de Cortes promovida por la Junta Central- ${ }^{16}$ había recibido el encargo «de recoger cuantas memorias históricas pudiese hallar acerca de las antiguas Cortes de Castilla, Aragón, Cataluña, Valencia y Navarra, y de informar cuanto fuese relativo a la reorganización y ceremonial de estos congresos». ${ }^{17}$ Capmany redactó una Memoria política-histórica sobre convocación y celebración de Cortes. El barcelonés denunció que «la Francia nos despojó a principios del siglo pasado de los restos de nuestra antigua libertad», en clara alusión a los decretos de Nueva Planta de Felipe V. Además, constató la gran diferencia entre «la

11 Javier Tajadura Tejada, «Constitución y Derechos Históricos: legitimidad democrática frente a la legitimidad histórica», Teoría y realidad constitucional, 22, 2008, pp. 139141; y José Antonio Maravall, «El mito de la tradición en el constitucionalismo español», Cuadernos Hispano Americanos, 329-330, 1997, pp. 547 y ss.

12 Julio Herrera, ;Serviles!: el grupo reaccionario de las Cortes de Cádiz, Fundación Unicaja, Málaga, 2007.

13 Carmen García Monerris, «Lectores de historia..., p. 96; y José María Portillo Valdés, «Imaginación y representación..., p. 271.

14 Acerca de los parlamentarios de los territorios de la antigua Corona de Aragón en las Cortes de Cádiz se pueden consultar los siguientes números monográficos: Germán Ramírez Aledón (Coord.), «Valencians, mallorquins i catalans a les Corts de Cadis», Afers, Vol. XXVI, 68, 2011, pp. 9-182; y el dossier «Los orígenes del parlamentarismo y la tradición de la Corona de Aragón, 1808-1823», Trienio: Ilustración y liberalismo, 61, 2013, pp. 7-164. Asimismo, véase Mikel Urquijo Goitia (Coord.), Diccionario Biográfico de parlamentarios españoles. Cortes de Cádiz, 1810-1814, Cortes Generales, Madrid, 2010.

${ }^{15}$ Lluís Ferran Toledano, «Historicisme i política de la classe dirigent catalana en el debat constitucional gadità», en Agustí Alcoberro y Giovanni Conrad Cattini (Eds.), Entre la construcció nacional $i$ la repressió identitària, Generalitat de Catalunya, Barcelona, 2012, pp. 203-218.

16 Manuel Morán Ortí, «La formación de las Cortes (1808-1810)», Ayer, 1, 1991, pp. $25-26$.

17 Federico Suárez, El proceso de la convocatoria a Cortes (1808-1810), Ediciones Universidad de Navarra, Pamplona, 1982, pp. 229-233. 
Corona de Castilla [a la que] el poder y representación de las Cortes fue débil e incompleto» y la Corona de Aragón y el Reino de Navarra: «¿La Corona de Aragón no tuvo por espacio de cinco siglos fueros, constituciones, libertades y franquezas invulnerables, Aragón, Valencia, Cataluña y Navarra no son de España y no lo eran antes?». Capmany evidenció que la evocación de una constitución histórica solamente se podía observar en el reino navarro y en los territorios que conformaron la antigua Corona de Aragón. De esta manera, no le resultó difícil vindicar las excelencias de la tradición constitucional catalana ${ }^{18}$ y foral aragonesa ${ }^{19}$ en oposición a la castellana: «Luego podemos decir que la proposición general de que España no ha tenido una Constitución legalmente fundada, reconocida y observada para sostener los derechos y libertades de la Nación es falsa, equivocada y ofensiva en las provincias de fueros, que componen una tercera parte de la Monarquía». ${ }^{20}$

Asimismo, Antonio de Capmany remitió a la Comisión de Cortes el 3 de diciembre de 1809 «un compendio de la práctica y modo de convocar Cortes en el reino de Aragón y en el de Valencia»; y quince días después «una noticia del modo y formalidad con que se celebran los congresos nacionales en Cataluña». ${ }^{21}$ Dichos trabajos se publicaron póstumamente en la obra titulada Práctica y estilo de celebrar Cortes en el reino de Aragón, principado de Cataluña, y reino de Valencia y una noticia de las Casti-

${ }_{18}$ Reciben el nombre de constituciones catalanas aquellas normas promulgadas por el conde de Barcelona y aprobadas por las Cortes catalanas, ya que eran la expresión legal de los acuerdos contractuales establecidos entre el rey y los tres brazos - el eclesiástico, el militar o noble y el real o de las villas - tras un proceso de negociación. Por ello, tenían preeminencia sobre las demás normas legales y sólo podían ser revocadas por las propias Cortes catalanas. Las primeras proceden de las Cortes de Barcelona de 1283 y las últimas de las Cortes catalanas de 1702. Véase Constitucions, capitols $i$ actes de cort: 1701-1702 i 1705-1706, edición facsimilar, estudio introductorio de Joaquim Albareda i Salvadó, Generalitat de Catalunya, Parlament de Catalunya, Barcelona, 2006.

19 Los fueros aragoneses atribuían el máximo valor a la costumbre y a la tradición como origen de su derecho y emanaban conjuntamente de las reuniones mantenidas en Cortes por ambas partes, rey-reino. Véase Jesús Delgado Echeverría, Los Fueros de Aragón, CAI, Zaragoza, 1997.

${ }_{20}$ Publicada y comentada por José Álvarez Junco, «Capmany y su Informe sobre la necesidad de una Constitución (1809)», Cuadernos Hispanoamericanos, 70, 1967, pp. 520-551.

${ }^{21}$ José María Portillo Valdés, Revolución de nación. Orígenes de la cultura constitucional en España, 1780-1812, Centro de Estudios Políticos y Constitucionales, Madrid, 2000, pp. 266 y ss. 
llas y Navarra $^{22}$. Capmany defendió la directa relación entre las Cortes medievales catalanas ${ }^{23}$, aragonesas ${ }^{24}$ y valencianas ${ }^{25}$ y las futuras gaditanas. Los viejos usos y costumbres de los territorios de la antigua Corona de Aragón ${ }^{26}$ se erigirían en la base de un proyecto válido para el conjunto de una nueva nación española ${ }^{27}$, ya que aportaban un legítimo antecedente autóctono de un constitucionalismo moderno - la nostalgia medieval fue una recurrente característica de la ideología liberal española-, evitando la habitual descalificación de los reaccionarios que presentaban cualquier idea de constitucionalismo como un contagio de los postulados políticos emanados del proceso revolucionario francés: «No presento el estado político de la Corona de Aragón por modelo perfecto de una Constitución, tal como acaso necesitan los pueblos para alcanzar y afianzar la última felicidad y libertad del hombre en sociedad [...]. Lo presento para mostrar al mundo poco instruido de nuestra antigua legislación hasta qué grado de libertad llegaron las provincias de aquella corona en siglos que hoy se les

22 Antonio de Capmany, Práctica y estilo de celebrar Cortes en el Reino de Aragón, Principado de Cataluña y Reino de Valencia, y una noticia de las de Castilla y Navarra, Imprenta de José Collado, Madrid, 1821.

${ }^{23}$ Eva Serra i Puig, «Butlletí bibliogràfic sobre les Corts Catalanes», Arxiu de textos catalans antics, 26, 2007, pp. 663-738.

24 Esteban Sarasa Sánchez et al., Aragón: Historia y Cortes de un Reino, Cortes de Aragón y Ayuntamiento de Zaragoza, Zaragoza, 1991.

25 Remedios Ferrero y Lluís Guia (Eds.), Corts i Parlaments de la Corona d'Aragó: Unes institucions emblemàtiques en una monarquia composta, Universitat de València, València, 2008.

${ }^{26}$ La Corona de Aragón fue lo que llamamos una «unión real» o monarquía compuesta que consiste en un aglomerado de territorios y grupos de súbditos, todos desiguales entre sí, con leyes y equilibrios políticos internos diferenciados bajo un único elemento común, el rey. Sin embargo, las instituciones jurídicas propias de los diversos territorios repitieron un modelo similar de estructura política: Cortes generales, Cortes individualizadas, Diputación de cada Reino, órganos municipales (consejos) y, en el ámbito de la justicia, la Real Audiencia y el Consejo Real. Asimismo, en el plano ritual y en el de la autorepresentación de la corona (ceremonial cortesano, rituales de coronación, exposición y enumeración de los títulos de la Casa real, órdenes de caballería, blasones y escudos de armas, etc.) se expresó la unidad del conjunto. Véase Ernest Belenguer Cebrià (Coord.), Història de la Corona d'Aragó, Edicions 62, Barcelona, 2007.

27 Capmany ya se había preguntado: «¿Qué sería ya de los españoles, si no hubiera habido aragoneses, valencianos, murcianos, andaluces, asturianos, gallegos, extremeños, catalanes, castellanos, etc. Cada uno de estos nombres inflama y envanece, y de estas pequeñas naciones se compone la masa de la gran Nación». Antonio de Capmany, Centinela contra los franceses, Gómez Fuentenebro, Madrid, 1808, p. 94. 
quiere llamar góticos, por no decir bárbaros, y cual en aquellos tiempos no había gozado ninguna nación en un gobierno monárquico». ${ }^{28}$

Capmany, al dar a conocer las diversas prácticas y estilos de celebrar Cortes, acreditó la existencia de un régimen constitucional previo: «[La Corona de Aragón] Era el país que tenía una Constitución, la cual, por los nudos con que estaba ligada, era por sí misma indisoluble. Y así perseveró, invulnerable hasta que las armas de Felipe II en Aragón, y las de Felipe IV en Cataluña, intentaron darle algunos asaltos; y últimamente, las de Felipe $\mathrm{V}$ la derribaron con mayor poder, por aquel derecho de conquista que se atribuyó con la guerra de Sucesión». ${ }^{29}$ Por tanto, el futuro diputado catalán mostró una cierta voluntad por recuperar un marco político propio para el Principado de Cataluña dentro de la monarquía hispánica, inspirado en el recuerdo de las antiguas leyes, instituciones y prácticas del modelo pactista de la antigua Corona de Aragón. ${ }^{30}$

A pesar de que Capmany evidenció que el código normativo y el sistema político medieval aragonés ${ }^{31}$ y catalán ${ }^{32}$ - contractualismo limitador del poder regio y protector de los privilegios, usos, costumbres, derechos, garantías y libertades tanto colectivas como individuales - ${ }^{33}$ podía inspirar un nuevo régimen constitucional, en Cádiz acabó imponiéndose un historicismo de raíz castellana ${ }^{34}$ - Jovellanos o

${ }_{28}$ Práctica y estilo de celebrar cortes..., pp. IV-V. Estudio introductorio de Josep Fontana, «Antoni de Capmany i les Corts catalanes», Editorial Base, Barcelona, 2007, pp. 5657.

${ }^{29}$ Práctica y estilo..., p. VI. Estudio introductorio de Josep Fontana, «Antoni de Capmany..., p. 60 .

30 Ernest Lluch, «Antoni de Capmany, el primer de tots», L'Avenç, 220, 1997, pp. 2427.

31 El pactismo se instituyó en las Cortes de 1283, por él el monarca de la Corona de Aragón se obligaba a legislar con la aprobación de la major i més sana part de las Cortes. Véase Enric Guinot Rodríguez, «Sobre la génesis del modelo político de la Corona de Aragón en el siglo XIII: Pactismo, Corona y Municipios», Res publica: revista de filosofía política, 17, 2007, pp. 151-176.

${ }_{32}$ Jaume Sobrequés, El pactisme a Catalunya: una praxis política en la història del país, Edicions 62, Barcelona, 1982.

${ }^{33}$ Por ejemplo, impedía cualquier arbitrio o injerencia derivada de la autoridad real, otorgaba libertad de residencia, aseguraba la inviolabilidad del domicilio y la correspondencia, garantizaba el derecho a no servir al ejército real si no era para defender territorio catalán o el derecho a no ser condenado sin pruebas. Véase Víctor Ferro, El dret públic català. Les institucions a Catalunya fins al decret de Nova Planta, Eumo, Vic, 1987.

${ }^{34}$ José Manuel Nieto Soria, Medievo constitucional. Historia y mito político en los orígenes de la España Contemporánea (ca. 1750-1814), Akal, Madrid, 2007. 
Martínez Marina - que no incorporó el catalán ${ }^{35}$ ni el del resto de los antiguos reinos de la Corona de Aragón, obviando así la construcción de un discurso histórico nacional forjado desde la periferia de la nación española. ${ }^{36}$

Gaspar Melchor de Jovellanos identificó la Historia con la tradición mediante la teoría de las leyes fundamentales ${ }^{37}$ - Constitución histórica nacional $^{38}$ - . Las Partidas, el Fuero Real y el Fuero Juzgo, las Leyes de Toro y la Nueva Recopilación - códigos y normas dispares que recopilaron los poderes del rey y de la nación- permitían establecer un vínculo entre la monarquía estamental y la constitucional - como forma de gobierno tradicional del reino español- mediante la idea de un pacto de sujeción entre el monarca y su pueblo, en virtud del cual éste trasladaba a aquél la soberanía - translatio imperii o pacto de traslación-. En las Cortes gaditanas, dicho argumentario, sirvió de inspiración para el sector realista reformador, con talante ilustrado - Despotismo ilustrado-, ya que eran herederos de la doctrina escolástica - aristotélico-tomista que reconocía la dualidad soberanía rey-reino - del Siglo de Oro español; admiradores del constitucionalismo inglés — dos cámaras: la alta de los privilegiados, donde estaban representados la nobleza y el clero; y la baja de los comunes -; prosélitos de Montesquieu - El espíritu de las Leyes (1748) - por su teoría de los cuerpos intermedios que exaltaba la aristocracia y propugnaba un poder ejecutivo fuerte; y, sobre todo, contrarios al pensamiento revolucionario francés de 1789 - Mably, Rousseau o Sieyès - por la consideración de una constitución emanada del poder consti-

35 «Los historiadores catalanes declaran siempre, solemnemente, su adhesión a la idea política de España como patria común y situaban el pasado catalán de libertades dentro de la tradición nacional española, lo que les llevaba a lamentar la escasa consideración que Cataluña recibía en las historias generales». Mariano Esteban de Vega, «En torno a la construcción cultural de España», en Ricardo Robledo, Irene Castells y María Cruz Romeo (Eds.), Orígenes del liberalismo. Universidad. Política. Economía, Universidad-Junta de Castilla y León, Salamanca, 2003, pp. 265-268.

36 José Álvarez Junco, «Memoria e identidades nacionales», en Justo Beramendi y María Jesús Baz (Eds.), Identidades y Memoria Imaginada, Universitat de València, València, 2008, pp. 181-200.

37 Santos Manuel Coronas González, «Las Leyes Fundamentales del Antiguo Régimen (Notas sobre la Constitución histórica española)», Anuario de Historia del Derecho Español, 65, 1995, pp. 127-217.

38 Joaquín Varela Suanzes-Carpegna, «La doctrina de la constitución histórica de España», Fundamentos, 6, 2010, pp. 307-359, especialmente pp. 309-323. 
tuyente de la nación - soberanía nacional y concepto racional-normativo de Constitución -.$^{39}$

Por su parte, Francisco Martínez Marina fue un referente para los liberales doceañistas más moderados. Para el asturiano, los godos - con sus leyes sabias y justas, el gobierno del pueblo, las instituciones representativas y la limitación del poder real (solamente ostentaban el poder ejecutivo por el pactismo: «fundamento de la libertad y freno del despotismo») - se erigieron en el punto de partida meta-histórico de un relato que consideró a los españoles por constituidos desde los remotos tiempos medievales - fundamento nacional, origen del estado o del reino-. La instauración del feudalismo supuso la pérdida de la libertad y de la independencia inicial, o sea, la desaparición de la constitución gótica. Para Martínez Marina, existió durante estos siglos bajo medievales una auténtica monarquía moderada o templada, la constitución mixta, aquella carta magna histórica española que los constituyentes gaditanos respectaron al eliminar los abusos cometidos por el despotismo de las dinastías austríaca y borbónica. Así pues, Marina intentó medievalizar las instituciones liberales del siglo XIX.40

\section{La táctica inmovilista de los realistas: el recurso a la tradición}

Para los diputados más conservadores, tal y como fijó la Junta Central en su decreto de 22 de mayo de 1809 sobre restablecimiento y convocatoria de Cortes, se había de «asegurar la observancia de las leyes fundamentales del Reino». ${ }^{41}$ Por dicho motivo, cuando José Espiga y Gadea propuso la creación de una comisión para reformar la legislación civil y otra para la criminal ${ }^{42}$, Ramón Lázaro de Dou alegó que la elaboración

39 Ignacio Fernández Sarasola, El pensamiento político de Jovellanos. Seis estudios, In Itinere, Oviedo, 2011.

40 Francisco Martínez Marina, Teoría de las Cortes. Grandes Juntas Nacionales de los Reinos de León y Castilla. Momentos de su constitución política y de la soberanía del pueblo, con algunas observaciones..., Imp. de Fermín Villalpando, Madrid, 1813; y Joaquín Varela Suanzes-Carpegna, Política y Constitución en España. 1808-1978, Centro de Estudios Políticos y Constitucionales, Madrid, 2007.

${ }^{41}$ Manuel Fernández Martín, Derecho parlamentario español, Imprenta de J. A. García, Madrid, 1885, Tomo II, pp. 559-561.

${ }^{42}$ Diario de Sesiones de Cortes, en adelante DSC, n. ${ }^{\circ} 132,5$ de febrero de 1811 , p. 500 . 
de un «Código perfecto de legislación» que comprendiera los diversos ámbitos de la administración pública era una tarea ingente e inviable «en las circunstancias presentes», sobre todo cuando era imprescindible la consulta de «todos los Códigos de nuestra legislación...Si se ha de contar con la legislación actual, ni aquí ni en Cádiz tenemos los cuerpos de nuestra legislación. ¿En dónde están las Constituciones de Cataluña? ¿En dónde los fueros de Aragón? ¿En dónde las leyes de las Provincias Vascongadas?». El cancelario de la Universidad de Cervera, la única del Principado, evidenció la necesidad de incorporar disposiciones de los diferentes corpus jurídicos de los reinos históricos para erigir un nuevo y unitario código legislativo, más si cabe cuando se habían de simplificar las leyes y evitar redundancias. No obstante, el jurista catalán se manifestó contrario a establecer «una reforma de ley con la generalidad y extensión con que se ha propuesto». De hecho, Dou, al tener bien presentes las costumbres y las tradiciones de cada territorio, únicamente fue partidario de derogar las leyes consideradas non gratas, sirviéndose de «el ejemplo que nos dio el Sr. D. Felipe V en Cataluña, y en algunas otras provincias [reinos de Valencia, Aragón y Mallorca]...Cuando se terminó la guerra de sucesión, se dudó mucho en Cataluña sobre variar del todo el sistema de la legislación: prevaleció la opinión contraria, derogándose solamente algunas leyes, estableciéndose otras, y renovándose la observancia de las más útiles. Así se hizo una obra grande, esto es, la nueva planta de Gobierno, que consiste en uno o dos pliegos, y forma uno de los autos acordados».$^{43} \mathrm{El}$ letrado barcelonés ejemplificó el enorme error que podía suponer la instauración de una legislación contraria al derecho consuetudinario y doctrinal. Dou se había postulado claramente a favor de la conservación del derecho civil catalán, incluso apostó por su integración en el ordenamiento normativo gaditano, eso sí, a costa de haber legitimado el Decreto de Nueva Planta de enero de 1716 que supuso para el Principado la abolición de las Cortes catalanas, de la Diputación del General y del Consell de Cent barcelonés. ${ }^{44}$

${ }^{43}$ DSC, n. ${ }^{\circ} 132,5$ de febrero de 1811, p. 502. Véase Ricardo García Cárcel, De los elogios a Felipe V, Centro de Estudios Políticos y Constitucionales, Madrid, 2002.

${ }_{44}$ Rápidamente, Espiga rebatió el inconveniente expresado por Dou: «Supone que se han de examinar todos los Códigos, y que estos no se hallarán a mano. Señor, en Cádiz se encontrarán, que no hay tanta falta de literatos. A más, si no se hallan, V. M. dará providencia para eso». DSC, n. ${ }^{\circ} 132,5$ de febrero de 1811, p. 502. 
Precisamente, el recurso a la tradición fue el argumento empleado por Jaime Creus para oponerse a la derogación de los señoríos. ${ }^{45} \mathrm{El}$ canónico de la Seo de Urgel se negó a aprobar la proposición del diputado por el reino de Galicia Alonso y López de «hacer reversibles a la Corona las enajenaciones con que está defraudada», basándose en la ley $3 .^{a}$ del título XXVI de la Partida 4. ${ }^{a}$ - «ningúnt home non puede ser vasallo de dos señores» $-{ }^{46}$, porque «se trata de aprobar sin discusión una proposición que va a destruir el sistema que siempre ha regido en España». ${ }^{47}$ Creus impugnó la facultad de crear ex novo una Constitución o un corpus legislativo, o sea, refutó el carácter constituyente de las Cortes reivindicado por los liberales doceañistas en virtud del principio de soberanía nacional. Además, ante la iniciativa del parlamentario por Soria, García Herreros, ${ }^{48}$ el eclesiástico catalán sostuvo que «se propone una medida que enteramente destruye el sistema que nació, digámoslo así, con la Monarquía de España, y se ha conservado hasta aquí», cuando justamente se había de conservar la legislación del «sistema general de la Monarquía» - Constitución histórica de la Monarquía hispánica- ${ }^{49}$ Asimismo, desacreditó la propuesta de García Herreros por afrancesada, o sea, antiespañola, al vincular la supresión de los señoríos con los preceptos revolucionarios franceses.$^{50}$ Finalmente, el doctor en teología reivindicó el derecho consuetudinario para legitimar el régimen señorial, aduciendo «lo perteneciente a las leyes y Constituciones de Cataluña», ya que algunas normativas prohibían a los reyes revocar ciertas donacio-

${ }^{45}$ La derogación de los señoríos jurisdiccionales suscitó uno de los debates más intensos y convulsos de las Cortes gaditanas. Para ampliar la información véase Francisco Hernández Montalbán, La abolición de los señoríos en España: 1811-1837, Biblioteca Nueva/ Universidad de Valencia, Madrid, 1999.

46 DSC, n. ${ }^{\circ} 243,1$ de junio de 1811, pp. 1161-1162.

47 DSC, n. ${ }^{\circ} 243,1$ de junio de 1811, p. 1163.

48 «desde hoy queden incorporados a la Corona todos los señoríos, jurisdicciones, posesiones, fincas y todo cuanto se haya enajenado, o donado, reservando a los poseedores el reintegro a que tengan derecho, que tengan derecho del examen de los títulos de adquisición». DSC, n. ${ }^{\circ} 243,1$ de junio de 1811, p. 1164.

49 DSC, n. ${ }^{\circ} 254,12$ de junio de 1811 , p. 1249.

50 «cuando los franceses en la anterior guerra [Guerra Gran (1793-1795)] procuraban calmar el ardor de los pueblos de Cataluña, convidándolos en sus proclamas con la abolición de todo señorío, de los diezmos y despojos de las iglesias, tanto más se aumentaba su odio y encono contra tan vil e irreligiosa Nación. En vano intentaban algunos, embebidos en las máximas, entonces dominantes en Francia introducir sordamente en el pueblo sus ideas». DSC, n. ${ }^{\circ}$ 254, 12 de junio de 1811, p. 1249. 
nes, como la «Constitución cuarta de sobresehiment de lluicions hecha en 1590 se dice ser contra el derecho natural y divino la facultad que se suponía a los Reyes de reintegrarse como si fuese vendido con pacto de retro de lo enajenado perpetuamente». ${ }^{51}$

Algunas usanzas y prácticas medievales inspiradas en el modelo político de la antigua Corona de Aragón también fueron rememoradas y reivindicadas durante el debate del articulado constitucional destinado a modificar el sistema electoral, representativo y parlamentario con el objetivo de preservar algunas prerrogativas de los estamentos feudales privilegiados - parte esencial de las leyes fundamentales - . Por ejemplo, Jaime Creus se opuso a la prohibición del derecho a voto y elección de los religiosos regulares del artículo treinta y cinco porque los prelados «ya de muy antiguo están en posesión de asistir a las Cortes. Se sabe que los abades de San Benito asistían a las Cortes de Navarra y Aragón». ${ }^{52}$ Además de Creus, se agregaron los votos contrarios del considerable - cuantitativamente hablando - núcleo conservador catalán: Vega, Morrós, Aités, Lladós, Papiol y el Marqués de Tamarit ${ }^{53}$ En la discusión del artículo cuarenta y seis, Francisco Morrós reclamó que los curas párrocos pudieran asistir a las juntas electorales por «la costumbre antigua, la piedad de los Reyes y la misma Junta Central mandó que asistiesen». ${ }^{54}$ Asimismo, José Vega y Sentmenat se opuso a la concepción liberal individualista de representación nacional establecida en el artículo veintisiete - «Las Cortes son la reunión de todos los Diputados que representan la Nación, nombrados por los ciudadanos en la forma que se dirá»-, manifestando su rechazo a la abolición del fuero territorial - ciudades con derecho de voto- .55

De la misma forma, los parlamentarios más apegados a la tradición invocaron la periodicidad de las Cortes de los territorios de la antigua Corona de Aragón para espaciar la celebración de las contemporáneas Cortes constitucionales. Durante el debate del artículo ciento cuatro — «se juntarán las Cortes todos los años en la capital del Reino»- Antonio de Capmany declaró que en los inicios de «las antiguas Cortes de Aragón» se reunía «la diputación todos los años [por ejemplo, según lo acordado en las Cortes catalanas celebradas en Barcelona en 1283 bajo

\footnotetext{
51 DSC, n. ${ }^{\circ} 254,12$ de junio de 1811, p. 1250.

DSC, n. ${ }^{\circ} 356,23$ de setiembre de 1811, p. 1904.

DSC, n. $^{\circ} 357,24$ de setembre de 1811, p. 1910.

DSC, $n .^{\circ} 358,25$ de setiembre de 1811, p. 1917.

55 DSC, n. ${ }^{\circ} 354,21$ de setiembre de 1811, p. 1895.
} 
el reinado de Pedro el Grande (1276-1285)], asimismo, en las Cortes de Aragón, reunidas en Zaragoza en 1283, el monarca concedió la obligación de reunirse periódicamente con los aragoneses en Cortes]; pero la experiencia hizo ver que era demasiado frecuente esta reunión anual, y que traía algunos inconvenientes». Hasta el punto que se dejó «a la voluntad del Rey, y perdiendo el período que antes guardaban fueron menos frecuentes, pues pasaban muchos años sin haberlas». No obstante, la Diputación del General conservaba el derecho de representar «a la Nación, y juntarla cuando había una necesidad extrema». Por tanto, según el parecer del diputado catalán, perfectamente, se podría recuperar y aplicar el procedimiento empleado por el sistema político medieval del Principado catalán y el Reino de Aragón «pues se deja a la diputación en libertad de que cuando haya un caso urgente e interesante a la Patria, pueda juntar las Cortes extraordinarias». Por ello, de acuerdo a la experiencia histórica de las Cortes catalanas y aragonesas «mi opinión será que hubiese Cortes ordinarias cuando más cada dos o tres años [tal y como se fijó en las Cortes catalanas de Lérida del año 1301 bajo el reinado de Jaime II de Aragón], atendiendo principalmente a las inmensas distancias que separan los países de los cuales han de venir Diputados para el Congreso nacional de las Españas».56

Un mayor poder regio también fue invocado en aras de la tradición, de acuerdo a la teoría de la soberanía compartida entre el rey y las Cortes. En el trascurso del análisis del artículo ciento dieciocho ${ }^{57}$ Jaime Creus defendió que el monarca presidiera el parlamento tal y como era costumbre en las cortes navarras y en las de la antigua Corona de Aragón: «Observo que en las Cortes de Aragón y de Navarra era el Rey el Presidente nato». ${ }^{58}$ De hecho, los diputados catalanes más apegados al realismo cuestionaron la soberanía nacional y la radical separación de poderes durante el examen del artículo ciento cincuenta y cinco. ${ }^{59}$ Por ejemplo, Dou expuso que «los Reyes de España, siendo así que no solo ejercían la soberanía que com-

56 DSC, n. ${ }^{\circ} 362,29$ de setiembre de 1811, p. 1950.

57 «Enseguida se procederá a elegir de entre los mismos Diputados, por escrutinio secreto y a pluralidad absoluta de votos, un presidente, un vice-presidente y cuatro secretarios, con lo que se tendrán por constituidas las Cortes, y la Diputación permanente cesará en todas sus funciones». DSC, n. $^{\circ}$ 364, 1 de octubre de 1811, pp. 1963-1964.

58 DSC, n. ${ }^{\circ} 364,1$ de octubre de 1811, p. 1965.

59 «El Rey para promulgar las leyes usará de la fórmula siguiente: N. (el nombre del Rey) por la gracia de Dios, y por la Constitución de la Monarquía española, Rey de las Españas...». DSC, n. ${ }^{\circ} 370,7$ de octubre de 1811 , p. 2008. 
prende el Poder ejecutivo, sino también la que incluye el legislativo y judiciario, promulgaban las leyes...» con el fin de recordar que antaño acumulaban los tres poderes. Por ello, sostuvo que la inclusión de la fórmula propuesta por la comisión de constitución estaría más conforme «con el sistema extranjero de nuestros vecinos que con el nacional» - fehaciente acusación de afrancesamiento-. De manera categórica, el cancelario de la Universidad de Cervera fue partidario de que «se ponga la fórmula en estilo antiguo». ${ }^{60}$

Un liberal moderado como Felipe Aner, para defender que el soberano tuviera la facultad de «declarar la guerra y hacer y ratificar la paz» - artículo ciento setenta y uno-, no dudó en rememorar que los «famosos aragoneses, celosos de su libertad, y constituidos entre potencias formidables, con las que sostenían continuas guerras; reservaron al Rey la facultad de declarar la guerra y hacer la paz, y únicamente se le imponía la obligación de oír para ello el dictamen de algunos ricos homes, seniorum consilio: así se explica el Fuero de Sobrarbe». Así pues, para el jurista catalán, el monarca doceañista había de poseer dicha facultad «siguiendo en esta parte la regla que nos prescribieron los aragoneses en tiempos no menos críticos que los presentes». ${ }^{61} \mathrm{Sin}$ duda, resulta extraño que el aranés Felipe Aner de Esteve no recordará que las Cortes catalanas poseían la facultad de efectuar declaraciones de paz y guerra, tal y como aconteció en las de 1473-1479, celebradas en Perpiñán y Barcelona bajo el reinado de Juan II de Aragón (1458-1479), centradas en conseguir la paz definitiva del Principado y recuperar los Condados de Rosellón y Cerdaña. ${ }^{62}$

Finalmente, otro reformista moderado como Capmany se escudó en la imperiosa necesidad de preservar el secreto para legitimar la intervención real en la validación de la paz a partir del recurso historicista: «al Rey D. Pedro III [de Aragón, el Grande], quien sin haberla consultado con las Cortes para la conquista de Sicilia, armó 500 naves en Cataluña y Valencia, y embarcó 20.000 hombres con motivo de los derechos que alegaba su mujer. Y tan lejos estuvo la Nación de negarle todos los socorros para esta empresa, que le adelantó las contribuciones de tres años, y no se

${ }^{60}$ DSC, n. $^{\circ} 370,7$ de octubre de 1811, p. 2009.

61 DSC, n. ${ }^{\circ} 372,9$ de octubre de 1811, p. 2029.

62 Isabel Sánchez de Movellán, «Política y constitucionalismo a través de la Diputació del General de Catalunya (1413-1479)», en DD.AA., El compromiso de Caspe (1412) cambios dinásticos y constitucionalismo en la Corona de Aragón, IberCaja, Zaragoza, 2013, p. 751. 
le preguntó para que eran, ni a dónde iba la expedición, porque suponían que el Rey no podía hacer ninguna cosa contra el bien de sus súbditos. Después de estar embarcados preguntó al Rey el almirante: ¿A dónde vamos? Y él respondió: si la camisa que traigo puesta supiera lo que pasa en mi cuerpo, le pegaría fuego». Según el historiador catalán, el monarca «fingió que iba contra el África: allí desembarcó su tropa, tomó refrescos, y desde aquella costa se dirigió a Sicilia de cuya expedición resultaron las famosas vísperas Rellianas». Así pues, un episodio de la historia de la antigua Corona de Aragón fue suficiente para justificar los opacos e independientes propósitos y designios reales. Antonio de Capmany se ratificó en su parecer al asegurar que «en España los Reyes han tenido siempre esta libertad, aun los de Aragón, cuya Constitución era más rígida» ${ }^{63}$ -inmutabilidad de ciertos principios e instituciones considerados esenciales-.

\section{Liberales y revolucionarios: El legado histórico como excelso recurso}

Los parlamentarios liberales también aprovecharon el decreto de 22 de mayo de la Junta Central ${ }^{64}$ — «medios de mejorar nuestra legislación, desterrando los abusos introducidos y facilitando su perfección»- para legitimar y validar el ex-novo y rupturista proceso constituyente gaditano. Para José Espiga y Gadea era ineludible la enmienda de la legislación previa, o sea, histórica: «Es innegable que nuestros Códigos contienen leyes admirables dictadas por la sabiduría y por el conocimiento del corazón humano; pero si se observan los diversos tiempos en que fueron establecidas, no se puede dudar de que es necesario reformarlas». Al examinar «nuestros Códigos; sepárense las leyes que no sean conformes a nuestros usos, nuestras costumbres y nuestras circunstancias; modifíquense las que deban sufrir alguna alteración, y si las leyes no son más que la moral aplicada a las diversas circunstancias de los hombres, redúzcanse todas a sus primeros principios». Además, el eclesiástico consideró fundamental la

${ }^{63}$ DSC, n. ${ }^{\circ} 376,13$ de octubre de 1811,p. 2061.

64 «la reflexión de que los desastres que la Nación padece han nacido únicamente de haber caído en el olvido aquellas saludables instituciones que en tiempos más felices hicieron la prosperidad y la fuerza del Estado. La ambición usurpadora de los unos, el abandono indolente de los otros las fueron reduciendo a la nada...». Manuel Fernández Martín, Derecho parlamentario español..., Tomo II, pp. 559-561. 
supresión de los principios feudales que habían dividido la jurisdicción para preservar la soberanía nacional «tan indivisible como ella misma». ${ }^{65}$

Espiga, designado vocal de la comisión de Constitución ${ }^{66}$, en la sesión del 9 de julio de 1811 «propuso que sería muy conveniente mudar los epígrafes que determinan la división de los tres poderes [redactado por el diputado extremeño liberal Muñoz Torrero], poniendo, por ejemplo, en vez de poder legislativo, Cortes o representación nacional, en vez de poder o potestad ejecutiva, Del Rey o de la dignidad Real, y en vez de poder judicial, De los Tribunales, con lo que se evitaría el que tuviese aire de copia del francés esta nomenclatura». De acuerdo con la recomendación del «señor Espiga», se acordó en la sesión del 3 de agosto alterar los títulos que «tratan de lo relativo a la potestad legislativa, ejecutiva y judicial». ${ }^{67}$ Evidentemente, el diputado catalán - tal y como enunció en el Discurso Preliminar ${ }^{68}$ explicitando «la originalidad y entronque con la tradición política española» de la Constitución doceañista - procuró diferenciarse nominalmente del proceso constitucional revolucionario francés para evitar la acusación de afrancesamiento y, por tanto, de antipatriótico. De hecho, el arcediano de Benasque participó y colaboró de la redacción de un Discurso preliminar a la Constitución $n^{69}$, concebido como obra colectiva de la Comisión para legitimar los principios esenciales de la carta magna gaditana: soberanía nacional, división de poderes, monarquía limitada y moderada, carácter representativo de unas cortes unicamerales, uniformidad legislativa y fiscal, libertad de imprenta e igualdad civil de los ciudadanos. ${ }^{70}$ Eso sí, presentados como una actualización de las leyes fundamen-

${ }^{65}$ DSC, n. ${ }^{\circ} 132,5$ de febrero de 1811 , p. 500.

${ }^{66}$ Las Actas se pueden examinar en el Archivo del Congreso de los Diputados, en adelante ACD, Vol. 25 de los Papeles de Fernando VII. También se pueden consultar las Actas de la comisión de constitución (1811-1813). Estudio preliminar por M. ${ }^{a}$ Cristina Diz-Lois, Seminario de Historia Moderna (Universidad de Navarra), Instituto de Estudios Políticos, Madrid, 1976.

67 Actas de la comisión de constitución..., pp. 62-63 y 163.

68 Javier Tajadura Tejada, «El Discurso Preliminar de Agustín de Argüelles a la Constitución de Cádiz», Pensamiento Constitucional, 8, 2001, pp. 415-430.

${ }^{69}$ Agustín de Argüelles, Discurso preliminar a la Constitución de 1812, introducción de Luis Sánchez Agesta, Centro de Estudios Constitucionales, Madrid, 1981. Según Sánchez Agesta el discurso «se debió en gran parte a las ideas y a la pluma de Argüelles, y hasta cierto punto de Espiga, que habían sido encargados de su redacción. Esta colaboración de Espiga con Arguielles debió ser efectiva, pues Espiga, hombre inteligente y estudioso, no tiene traza de mero amanuense», p. 22.

70 Ibid., p. 42. 
tales quebrantadas por el absolutismo. A pesar de que, por ejemplo, en el texto constitucional doceañista se trasladaba la soberanía del monarca a la Nación.

Según el Discurso «nada ofrece la Comisión en su proyecto que no se halle consignado del modo más auténtico y solemne en los diferentes cuerpos de la legislación española... armonía de concordancia cuanto tienen dispuesto las leyes fundamentales de Aragón... en todo lo concerniente a la libertad e independencia de la nación, de los fueros y obligaciones de los ciudadanos». ${ }^{71}$ Por tanto, de acuerdo con el Discurso, el proceso constituyente gaditano no era ni novedoso ni foráneo porque solamente pretendía restaurar una nacional tradición constitucional: los «antiguos fueros y libertades...de donde se arrancaron con escándalo universal leyes benéficas y liberales» ${ }^{72}$; ya que, conforme al Discurso, el despotismo ejercido por las dinastías extranjeras - austríaca y borbónica- causó «un olvido casi general de nuestra verdadera constitución». ${ }^{73}$ Incluso, la censura establecida por el régimen absolutista prohibió «la lectura de los historiadores aragoneses, que tanto se aventajan a los de Castilla, nada deja que desear al que quiera instruirse de la admirable constitución de aquel reino... espíritu de verdadera libertad e independencia, amor al orden y a la justicia». ${ }^{74}$

Precisamente, merced a los conocimientos históricos de la dignidad de la catedral de Lérida, el Discurso también justificó la tarea legislativa del Congreso gaditano por la conveniente recuperación del sistema constitucional, foral y pactista de la antigua Corona de Aragón, un idílico modelo protector de los derechos y de las libertades del pueblo. De hecho, acorde al Discurso «ninguna nación de Europa puede acaso presentar leyes más filosóficas ni liberales, leyes que protejan mejor la seguridad personal de los ciudadanos, su honor y su propiedad, si se atiende a la antigüedad de su establecimiento, que la admirable Constitución de Aragón». ${ }^{75}$ Es más, según el Discurso, su principal virtud radicaba en la separación de poderes que, obviamente, limitaba el poder regio: «notable suceso de Cataluña en el año 1462, en que los estados de aquel principado, después de haberse resistido a don Juan II de Aragón, le depusie-

\footnotetext{
71 Ibid., p. 67.

72 Ibid., p. 69.

73 Ibid., p. 70.

74 Ibid., p. 69.

75 Ibid., p. 96.
} 
ron solemnemente del trono... Aragón fue en todas sus instituciones más libre que Castilla» ${ }^{76}$; ya que, sus cortes restringían la autoridad del ejecutivo: «Su objeto era oponerse abiertamente a la usurpación que hacía el rey o sus ministros de los fueros o libertades del reino... En Aragón se miraba la frecuente convocación de Cortes como el medio más eficaz de asegurar el respeto y la observancia de las leyes ${ }^{77} \ldots$ como el de no podérseles dar tormento, cuando al mismo tiempo en Castilla y en toda Europa estaban en toda su fuerza el uso de esta prueba bárbara y cruel... En 1283, en el reinado de Pedro III, llamado el Grande, se estableció: Que el señor Rey faga Cort general de aragoneses en cada un año una vegada». ${ }^{78}$ Pero la unión «de Aragón y de Castilla fue seguida muy en breve de la pérdida de la libertad» ${ }^{79}$, por tanto, en Cataluña, a partir del reinado de la monarquía autoritaria de los Austrias ${ }^{80}$ se inició un despotismo que solamente se anuló a partir de la promulgación del decreto de 24 de septiembre de 1810 , aquel que otorgó la soberanía a la nación ${ }^{81}$ y permitió legitimar el subsiguiente y revolucionario proceso constituyente gaditano. ${ }^{82}$

Justamente, la soberanía nacional y el recurso historicista validaron una de las mayores revoluciones del ordenamiento jurídico, la de-

76 Ibid., p. 71.

77 A pesar de que las antiguas Cortes españoles jamás ejercieron la potestad legislativa con pleno derecho, ya que solo poseían el derecho de representar y de suplicar, según la Constitución la potestad de hacer leyes corresponde esencialmente a las Cortes «restableciendo así la tradición de las Cortes de Aragón, Navarra y Castilla». Ibid.

78 Ibid., pp. 72-73. Así mismo, véase Aquilino Iglesia, «La constitució de 1283», L'Avenç, 74, 1984, pp. 47-48.

79 Agustín de Argüelles, Discurso preliminar a la Constitución de 1812..., p. 76.

80 En buena medida porque las Cortes fueron convocadas cada vez menos, ya que suponían un freno al poder absoluto del rey. Eso sí, la Generalidad, como órgano encargado de velar por el cumplimiento de las Constituciones de Cataluña, fue ganando en fuerza y protagonismo. Véase Joan Lluís Palos, Catalunya a l'Imperi dels Àustria, Pagès editors, Lleida, 1994; y Miquel Pérez Latre, La Generalitat de Catalunya en temps de Felip II. Política, administració i territori, Afers, Catarroja-Barcelona, 2004.

81 DSC, n. ${ }^{\circ} 1,24$ de septiembre de 1810, pp. 3-4.

82 Por ejemplo, merced al decreto de 24 de septiembre el Congreso gaditano se erigió en la máxima autoridad judicial, sustrayendo a la Regencia dicha decisiva potestad. En la sesión pública de 19 de noviembre de 1810 Felipe Aner defendió «con ejemplos de la legislación de Navarra y de Cataluña que el juicio de los administradores de la suprema autoridad siempre se le habían reservado las Cortes, sin cometer tales negocios a personas de fuera». Las Cortes estaban legitimadas a juzgar a los jueces, no por derecho, pero si «por lo menos de hecho y por consentimiento de la nación había residido la soberanía». Joaquín Villanueva, Mi viaje a las Cortes, Imprenta nacional, Madrid, 1860, p. 58. 
rogación de los señoríos jurisdiccionales. Felipe Aner recordó que «algunos señores preopinantes han ilustrado lo que en esta materia se observó en la Corona de Aragón» para poder alegar que el «conquistador de Valencia D. Jaime I, en virtud del convenio hecho en las Cortes de Monzón, repartió por donación a los Obispos, ricos-hombres y otros que concurrieron a la conquista de Valencia, alquerfas, castillos, pueblos y tierras, con que quedaron heredados muchos caballeros aragoneses y catalanes». ${ }^{83}$ Los liberales vincularon los señoríos con el derecho de conquista del reino valenciano. De hecho, el romanticismo permitió a los liberales más radicales equiparar la lucha que sostenía el pueblo español contra Napoleón con la reconquista de los territorios sarracenos. ${ }^{84}$ Además, según el jurista catalán «D. Jaime II, a pesar de haber establecido la integridad del Reino, y jurado guardarla en las Cortes de Tarragona de 1319, menoscabó considerablemente el Reino con las enajenaciones que hizo contra lo que había jurado». ${ }^{85}$ Incluso el «Rey D. Pedro [IV de Aragón, el Ceremonioso (1336-1387)] con motivo de la guerra que sostuvo contra el Rey de Castilla, llegó hasta el extremo en 1356 de dar poderes a algunos sujetos para que pudiesen vender, enajenar, empeñar y dar a censo perpetuamente o por tiempo por cualquier precio, y a cualquier persona, lugares, villas, castillos, jurisdicciones y demás derechos que le perteneciesen en el reino de Valencia». Por tanto, como se ampliaron notoriamente e ilegalmente las originarias alienaciones, las Cortes habían de expedir un decreto para incorporar a la Corona hispánica todas las jurisdicciones ejercidas por los señores particulares, las fincas indebidamente alienadas o donadas y todas las que por pacto $o$ ley tenían expedido el derecho de reversión. ${ }^{86}$

La tradición foral y constitucional y el modelo político e institucional de la antigua Corona de Aragón también sirvieron de inspiración a los diputados catalanes liberales para defender los postulados más reformistas durante el debate del articulado de la Constitución doceañista. Por ejemplo, el artículo noventa y uno ${ }^{87}$ pretendía que los eclesiásticos regulares

83 DSC, n. ${ }^{\circ} 249,7$ de junio de 1811, p. 1207.

84 Juan Sisinio Pérez Garzón, Las Cortes de Cádiz. El nacimiento de la nación liberal (1808-1814), Síntesis, Madrid, 2007, p. 32.

85 DSC, n. ${ }^{\circ} 249,7$ de junio de 1811, p. 1207.

${ }^{86}$ DSC, n. . 249, 7 de junio de 1811, p. 1208.

87 «Para ser Diputado de Cortes se requiere ser ciudadano que esté en el ejercicio de sus derechos, mayor de 25 años, y que haya nacido en la provincia, o este avecindado en 
no pudieran ser elegidos parlamentarios a Cortes. Joaquín Lorenzo Villanueva ${ }^{88}$, diputado eclesiástico valenciano, solicitó la admisión de una adición para que después de las palabras «bien sea del estado seglar o del eclesiástico secular» se añadiera «o Prelado eclesiástico regular», ya que «en la Junta de Caspe ${ }^{89}$, en que se comprometió todo el reino de Aragón, y que fue compuesta de solo nueve sujetos, los tres de ellos fueron regulares. En ellos puso su confianza todo aquel reino»..$^{0}$ A la sazón, Antonio de Capmany intervino «para ilustrar al Congreso sobre un hecho histórico que ha alegado el señor Villanueva en apoyo de su proposición». Según el historiador «es innegable que en las Cortes de Valencia, como en las de Cataluña y de Aragón, concurrían y eran llamados de derecho Prelados de órdenes religiosas», pero solamente asistían los abades y los priores de monasterios que poseían señoríos feudales, nunca en calidad de regulares porque por ley constitucional estaban excluidos del mismo modo que lo estaban los miembros del clero secular inferior. Así pues, de acuerdo al criterio del parlamentario catalán los obispos y abades concurrían como señores territoriales y jurisdiccionales «de ciertos pueblos dependientes de sus mitras». Sentenciando Capmany que «por un principio fundamental de la constitución de aquellas provincias desde el siglo XIII en que se instituyeron los tres brazos o estamentos, el que se llamaba eclesiástico, porque se componía de personas eclesiásticas, nunca fue convocado como representación de la Iglesia en el concepto místico y espiritual, sino de su jurisdicción temporal, bajo de este respecto eran convocados los nobles de primera y segunda jerarquía, no como tales puramente, sino como señores territoriales, porque allí la nobleza poseía tierras propias o dominios directos». Por tanto, para el filólogo «en aquellas provincias solo el derecho de propiedad en uno y otro estado constituía el derecho de representación en las Cortes». Además, Capmany rebatió a Villanueva «en cuanto al Congreso de Caspe» porque «aquel Congreso, nombrado por convenio de las tres provincias en tan largo interregno, no era el de unas Cortes, sino

ella con residencia a lo menos de siete años, bien sea del estado seglar, o del eclesiástico secular; pudiendo recaer la elección en los ciudadanos que componen la junta, o en los de fuera de ella». DSC, n. ${ }^{\circ}$ 359, 26 de septiembre de 1811, p. 1925.

${ }^{88}$ Germán Ramírez Aledón (Ed.), Valencianos en Cádiz. Joaquín Lorenzo Villanueva y el grupo valenciano en las Cortes de Cádiz, Biblioteca de las Cortes de Cádiz, Cádiz, 2008.

89 DD.AA., El compromiso de Caspe (1412): cambios dinásticos y constitucionalismo en la Corona de Aragón, Obra Social de IberCaja, Zaragoza, 2013.

90 DSC, n. ${ }^{\circ}$ 359, 26 de septiembre de 1811,p. 1926. 
una junta especial de nueve jueces árbitros o compromisarios para decidir un pleito entre cuatro Príncipes pretendientes a la sucesión de la Corona. Se componía de letrados y Caballeros, y también de teólogos como consultores en el fuero interno».$^{91}$ Así pues, el historiador catalán legitimó la exclusión de los regulares a partir de la habitual práctica de las antiguas Cortes Generales de la Corona de Aragón y las particulares de Valencia, de Cataluña y de Aragón - asistencia únicamente en calidad de señores feudales - .

El mismo Capmany, durante la discusión del artículo ciento veinticinco $^{92}$, con la finalidad de mitigar el despotismo gubernamental, se opuso a que asistieran los secretarios del despacho a las deliberaciones parlamentarias, solicitando que «se adoptase un sistema semejante al que se practicaba en las Cortes de Aragón, las cuales en tales lances nombraban los tratadores, esto es, una comisión especial encargada de tratar y discutir las propuestas o proyectos que se presentaban por parte del Gobierno, oyendo a sus autores; la cual después informaba a las Cortes del resultado, y estas en vista de todo aportaban o desechaban las propuestas». ${ }^{93}$ Así que, el secretario perpetuo de la Real Academia de la Historia defendió la separación de poderes y, especialmente, la no ingerencia del ejecutivo en el legislativo evocando el ceremonial con el que procedían las Cortes medievales pactistas de la antigua Corona de Aragón, en concreto, mediante el elogio y la vindicación de la figura de los tratadores, efectivamente, a quienes se les encomendaba la negociación de los temas debatidos en el seno de los diferentes brazos o estamentos sociales.

Asimismo, la fijación de períodos para las reuniones de las Cortes ordinarias - pervivencia de las prácticas tradicionales - fue compensada por la creación de una Diputación permanente de Cortes ${ }^{94}$ concebida como órgano de vigilancia para impedir los excesos o actuaciones anticonstitucionales del gobierno o de la Corona y así poder garantizar la con-

91 DSC, n. ${ }^{\circ} 359,26$ de septiembre de 1811, p. 1926.

92 «Tampoco deliberarán cuando se presenten los Secretarios del Despacho para hacer algunas propuestas a nombre del Rey». DSC, n. ${ }^{\circ}$ 364, 1 de octubre de 1811, p. 1966.

93 DSC, n. ${ }^{\circ}$ 364, 1 de octubre de 1811, p. 1966.

94 Artículo ciento cincuenta y siete: «Antes de separarse las Cortes nombrarán una diputación, que se llamará diputación permanente de Cortes, compuesta de siete individuos de su seno, tres de las provincias de Europa y tres de las de Ultramar, y el séptimo saldrá por suerte entre un Diputado de Europa y otro de Ultramar». DSC, n. ${ }^{\circ} 370,7$ de octubre de 1811, p. 2011. 
tinuidad parlamentaria..$^{95}$ Antonio de Capmany avaló la instauración de la Diputación permanente de Cortes por su analogía con la Diputación del General o Generalidad. ${ }^{96}$ Por tanto, la Constitución de Cádiz incorporaba la Diputación con un sentido moderno, pero no la creaba ex novo. Durante el debate de su primera facultad - velar por la vigilancia de la carta magna «para dar cuenta a las próximas Cortes de las infracciones que haya notado» ${ }^{97}$ - el erudito historiador rememoró la función ejercida por la Generalidad en la defensa de los derechos y de las libertades emanadas de los fueros aragoneses y valencianos y de las constituciones catalanas: «Había esta diputación en Cataluña y en toda la Corona de Aragón, establecida por leyes constitucionales de la tierra, que era el custodio de ellas de unas Cortes a otras. Este respetable cuerpo nacional salvó aquellas provincias de la arbitrariedad de los Reyes, y mantuvo invulnerables sus fueros y libertades contra cualquier tentativa de la corte: los abusos, trasgresiones y contrafueros eran reclamados y citados a reparación con jui-

95 Miguel Artola, «La monarquía parlamentaria», en Miguel Artola (Ed.), Las Cortes de Cádiz, Marcial Pons, Madrid, 2003, p. 118.

${ }^{96}$ Aunque la génesis de la Diputación del General haya que adscribirla a finales del siglo XIII y la primera mitad del siglo XIV (caso del Principado de Cataluña - reunión de Cortes celebradas en Monzón en 1289- y el reino de Valencia), su implementación oficial hay que situarla tras las Cortes Generales de Monzón de 1362-1363 bajo el reinado de Pedro el Ceremonioso mediante la creación del impuesto de las «Generalidades» para financiar la guerra con Castilla. La Diputación del General se instituyó como un órgano de delegación permanente de las Cortes con una primigenia y eminente función económica: recaudar el «servicio» o tributo que los brazos concedían al rey a petición suya. La Diputació del General de Catalunya, con representación estable en Cataluña desde 1359 y sede fija en Barcelona a partir de 1365, poseía atribuciones propias, ya que también ejecutaba las resoluciones de las Cortes Catalanas, recaudaba impuestos (drets del General) y los administraba, podía emitir deuda pública (censals), mantenía un ejército y una flota y, además, velaba por el cumplimiento de las leyes y las constituciones (l'observança del dret general de la terra). Según Ignacio Rubio y Cambronero constituye la institución «más importante que ha creado la España medieval», La Diputación del General de Cataluña en los siglos XV y XVI, vol. I, Diputación Provincial de Barcelona, Barcelona, 1950, p. 17. De acuerdo al criterio de Carmen Corona Marzol «durante el Medioevo no existió una corporación que representase de forma tan clara al territorio», «Las instituciones políticas en la Corona de Aragón desde sus orígenes al reinado de Carlos II», Millars: Espai $i$ historia, 32, 2009, p. 111. Asimismo, véase Isabel Sánchez de Movellán, La Diputació del General de Catalunya (1413-1479), Institut d'Estudis Catalans i Generalitat de Catalunya, Barcelona, 2004; y Maria Teresa Ferrer i Mallol, «Les Corts de Catalunya i la creació de la Diputació del General o Generalitat en el marc de la guerra amb Castella (1359-1369)», Anuario de Estudios Medievales, 34/2, 2004, pp. 875-938.

${ }_{97}$ Artículo ciento sesenta. DSC, n. ${ }^{\text {o } 371,8}$ de octubre de 1811, p. 2016. 
cio formal sin que ningún Rey se mostrase ofendido, porque la queja y la oposición eran legales». Así pues, merced a la actuación de la Diputación General como órgano de garantía constitucional se preservaron las prerrogativas de la despótica voracidad regia. Precisamente, para salvaguardarlas de nuevo, según el parecer del parlamentario catalán, el artículo había de incorporar «el orden con que ha de velar» y los medios para representar o reclamar las infracciones, a partir del ejemplo de «la guerra de los comuneros», ya que «en Cataluña no se atrevió Carlos V, sin embargo de sus deseos de romper obstáculos a su voluntad y poderío, a quebrantar las leyes y estatutos patrios, como lo hizo en la Corona de Castilla, siendo así que era Monarca de toda España». ${ }^{98}$ Ciertamente, los liberales doceañistas apelaron a la historia para demostrar que la soberanía pertenecía por esencia y en exclusiva a la Nación, pero fue usurpada por el absolutismo imperial. Ante tal injusticia, las Cortes gaditanas, mediante el articulado constitucional, habían de recuperar la libertad y la independencia de los pueblos hispánicos. De la misma forma, Antonio de Capmany evidenció su anhelo por modernizar la Corona y la Nación española a partir de la experiencia institucional catalana y aragonesa, llegando a avalar una Generalidad para toda la monarquía hispánica.

Además, Capmany, al percatarse que la Diputación permanente quedaba vacía de contenido porque no se le dotaba de instrumentos sustantivos ${ }^{99}$, insistió en la necesidad de conferir a sus integrantes preeminentes potestades, ya que en el artículo «nada se dice de la autoridad de este cuerpo ni de las facultades de sus individuos», ni tan solo que tuvieran un cuaderno de apuntes para registrar las infracciones, o sea, el Cuaderno de Greuges, quejas o agravios que presentaban los miembros de las Cortes aragonesas o catalanas cuando creían que el Rey había incumplido sus

98 DSC, n. ${ }^{\circ} 371,8$ de octubre de 1811, p. 2018. En su «Informe» a la Junta Central Capmany ya había recomendado que una vez que el monarca disolviera el Congreso acabadas las sesiones, designase una diputación de individuos para reclamar contra las posibles infracciones constitucionales: «Esta Diputación General, que en Cataluña, Aragón y Valencia se estableció a fines del siglo XIV para estos importantes objetos, y para la recaudación y administración de las rentas públicas (...), retuvo firme e ilesa su Constitución política, civil y económica por tantos siglos». Más si cabe, cuando en Castilla no existía una «autoridad nacional» que pudiera impedir los abusos del monarca o de sus ministros. José Álvarez Junco, «Capmany y su Informe..., pp. 549-550.

99 Ángel Luis Alonso de Antonio, «La diputación permanente en la Constitución de Cádiz o el intento frustrado de crear un órgano con funciones de garantía constitucional», Revista de Derecho Político, 83, 2012, pp. 169 y 186-195. 
compromisos: «En la Corona de Aragón protestaban los Diputados, que era más que reclamar. No había entonces libertad de imprenta, y por eso la diputación era el censor público del supremo poder. De todos modos, es un freno legal el reclamar, y es un freno que sin chocar con los demás poderes mantiene la observancia de las leyes...En Cataluña no había acción popular contra los agravios públicos, no había libertad de escribir; por eso la diputación absorbía este derecho, y venía a ser tutor de la Nación». ${ }^{100}$ El diputado barcelonés, excelente conocedor de la historia de la antigua Corona de Aragón, evocó las virtudes de la Generalidad o Diputación permanente de las Cortes catalanas y aragonesas para preservar la separación de poderes, restringir el poder del ejecutivo y perpetuar el régimen constitucional o foral, o sea, el histórico y consuetudinario ordenamiento jurídico, más si cabe cuando «se deposita en ella la defensa de los derechos nacionales conquistados y se la considera por la Nación el cuerpo conservador y custodio de sus derechos y libertad».101

También cabe destacar que los liberales sometieron la figura del monarca a la voluntad nacional ${ }^{102}$, como quedó establecido en el título IV de la Constitución. A pesar de que las doce restricciones del artículo ciento setenta y dos eran insólitas en la tradición monárquica española ${ }^{103}$, Antonio de Capmany se postuló a favor de la segunda ${ }^{104}$ «recurriendo a la historia, aunque me llamen anticuario»; preguntándose «¿Qué le aconteció al Rey D. Alonso V de Aragón [el Magnánimo (1416-1458)] de vuelta de la expedición a Nápoles, cuando perdió la batalla naval contra les genoveses?». El historiador aleccionó al Congreso con su encarcelamiento, junto con el de todos los príncipes de la familia real, por el Duque de Milán. ${ }^{105}$ De hecho, con la excusa de evitar «estos peligros y desgracias a un reino» el parlamentario catalán se opuso a que el monarca comandase personalmente el ejército «fuera de las fronteras del Reino, ni que se embarque

100 DSC, n. $^{\circ} 371,8$ de octubre de 1811, p. 2018.

101 Escrito de Antonio de Capmany, recogido en Adolfo de Castro, Cortes de Cádiz, Complementos de las Sesiones verificadas en la Isla de León y en Cádiz, tomo I, Imprenta de Prudencio Pérez de Velasco, Madrid, 1913, p. 485.

102 K. Marx sostuvo que la limitación del poder regio fue «el rasgo más combativo de la Constitución de 1812». Karl Marx y Friedrich Engels, Revolución en España, Ariel, Barcelona, 1970 , p. 110.

103 María Cruz Romeo Mateo, «Nuestra antigua legislación constitucional..., p. 98.

104 El monarca no se podía ausentar del reino sin el consentimiento de las Cortes «y si lo hiciere, se entiende que ha abdicado». DSC, n. ${ }^{\circ} 378,15$ de octubre de 1811, p. 2086.

105 DSC, n. ${ }^{\circ} 378,15$ de octubre de 1811, p. 2086. 
para expedición naval. No le faltarán generales de mar y tierra si procura crearlos y conservarlos». ${ }^{106}$ Así pues, nuevamente, los políticos doceañistas catalanes no dudaron en servirse de argumentos históricos para intentar justificar y, por tanto, validar cualquier precepto del articulado constitucional.

Del mismo modo, José Espiga y Gadea defendió la instalación del Consejo de Estado porque era «una verdad demostrada desde el origen de nuestra Monarquía». La dignidad de la catedral de Lérida, emulando a Francisco Martínez Marina, se remontó a los tiempos de los godos - evocación del goticismo - para hallar su génesis, cuando se denominaba Consejo de guerra. De hecho, según el dictamen del diputado representante de la Junta Superior del Principado, la comisión constitucional no había alterado sus competencias, solamente había restablecido una parte del «Gobierno en el estado que tuvo en los tiempos más gloriosos de nuestra Monarquía» ${ }^{107}$. Espiga recurrió a la recuperación de la tradición hispánica medieval - monarquía moderada - para poder legitimar una institución instituida originariamente por la Constitución de Bayona ${ }^{108}$, ya que el arcediano de Benasque estaba convencido de que era imprescindible para contener las intrigas ministeriales y el despotismo gubernamental: «No dude V. M. [las Cortes de Cádiz] un instante de su establecimiento: él solo podrá ilustrar a los Reyes para que no sean jamás sorprendidos por la aducción de los privados, y él solo podrá descubrir los caminos tortuosos por donde se les hace marchar hasta llegar a la ruina de la Nación». ${ }^{109}$ Efectivamente, el Consejo de Estado, al asignársele la tarea de velar por la pulcritud durante el proceso de formalización y elaboración de las leyes y de los decretos, se erigió en el referente para desarrollar un Estado legal, donde la ley se convirtiera en norma pública. ${ }^{110}$

Los liberales también se escudaron en el recurso historicista para humanizar el sistema judicial. Mediante el artículo trescientos treinta y tres se sancionó que «no se usará nunca del tormento ni de los apremios», certificándose así el decreto de 22 de abril de 1811. Sin duda, la abolición

106 DSC, n. ${ }^{\circ} 378,15$ de octubre de 1811, p. 2087.

107 DSC, n. $.390,27$ de octubre de 1811, p. 2160.

108 Ignacio Sarasola Fernández, La Constitución de Bayona (1808), Iustel, Madrid, 2007; y Raúl Morodo, Las Constituciones de Bayona (1808) y de Cádiz (1812), Biblioteca Nueva, Madrid, 2011.

109 DSC, n. $^{\text {o } 390, ~} 27$ de octubre de 1811, p. 2161.

110 Juan Sisinio Pérez Garzón, Las Cortes de Cádiz..., p. 137. 
del martirio y la substitución de la pena de la horca por el garrote por razón del decreto de 24 de enero de 1812 dignificaron el procedimiento penal. Desde tiempos inmemoriales la tortura había servido para obtener cualquier declaración de culpabilidad. Según Argüelles y Espiga «el juramento con que procura arrancarse de la boca del reo la confesión de su delito no se exige en el principado de Cataluña». ${ }^{111}$ Afirmación refrendada por el conservador moderado ${ }^{112}$ Ramón Lázaro de Dou: «me conformo en lo sustancial de la ley; y tanto más, cuanto ella es más conforme con la legislación de mi país (Cataluña)». ${ }^{113}$ Asimismo, haciendo gala de su vasta sapiencia, el cancelario de la Universidad de Cervera reveló la desigual práctica procesal de la Corona de Aragón y del Reino de Castilla: «en Aragón entiendo que no estaba autorizado: en Cataluña solo se daba lugar a la cuestión del tormento en el caso de hallarse el reo condenado ya a muerte y convicto de haber cometido el delito con compañeros, que no quería declarar: entonces se daba el tormento in capita sociorum; pero ad erswendam veritatem, como decían, se ha dado rarísima vez, porque en dicha provincia, en caso de persistir el reo negativo, purgaba la sospecha que tenía contra sí, y con la fuerte presunción que resultaba a su favor, se le ponía en libertad: por esto se pasaba casi un siglo sin verificarse la cuestión de tormento ad erswendam veritatem». ${ }^{114}$ Así pues, los doceañistas se valieron de la jurisprudencia de la antigua Corona de Aragón para establecer una práctica judicial protectora de la dignidad humana.

Finalmente, durante el transcurso del debate del capítulo único del título X de la Constitución - «De la observancia de la constitución y modo de proceder para hacer variaciones en ella»- Felipe Aner advirtió que «de nada servirán los desvelos y afanes de V. M. [las Cortes de Cádiz] en restablecer la sabia, respetable y antigua Constitución de la Mo-

111 Agustín de Argüelles, Discurso preliminar..., p. 111.

112 En el plano político fue partidario de reformas en el marco de la monarquía absoluta primero, y en ocasión del vacío de poder en 1808, defensor de una monarquía constitucional a la inglesa, con una fuerte representación de los estamentos propietarios y del territorio. Eso sí, en paralelo a la aparición en Cataluña de una interpretación revolucionaria del proceso constituyente gaditano, Dou fue uno de los principales consultores del reaccionarismo antiliberal. Véase Lluís Ferran Toledano, «Dou y Bassols, Ramón Lázaro de», en Mikel Urquijo Goitia (Coord.), Diccionario de Parlamentarios...

113 Cabe recordar que en el debate relativo a las causas civiles y criminales en las audiencias del artículo 261 Dou sostuvo que era «conforme con [lo dispuesto en] la Constitución de Cataluña, [y la] de Navarra». DSC, n. ${ }^{\circ}$ 422, 28 de noviembre de 1811, p. 2345.

114 DSC, n. ${ }^{\circ} 202,21$ de abril de 1811, p. 906. 
narquía española [Constitución histórica nacional], si al mismo tiempo no adoptase V. M. todas las medidas convenientes para su estabilidad y observancia». ${ }^{115} \mathrm{El}$ goticista diputado catalán también certificó que «el desprecio y olvido de nuestra Constitución ha conducido a la Nación el estado deplorable en que se halla». De hecho, el jurista se preguntó: «¿de qué habrían servido nuestros trabajos, de qué tanta sangre vertida gloriosamente en todo el ámbito de la Península para mantener la independencia nacional que la Constitución trata de asegurar?». Dadas las críticas circunstancias - siglos de despotismo y atroz invasión napoleónica - y la fervorosa lucha patriótica se habían de revestir las leyes constitucionales de unos requisitos jurídicos especiales para asegurar su inmutabilidad y cumplimiento, tal y como ejecutaron «todas las naciones, así antiguas como modernas, que han querido darse una Constitución». Aner legitimó la perpetuación de la restituida Constitución española a partir del ejemplo heleno: «¿Qué de afanes y desvelos no costo a los legisladores griegos el establecer su Constitución, y el contener la impaciencia y veleidad del pueblo (siempre amante de novedades para que no variasen las leyes constitucionales?». No siendo juicioso que «nosotros, después de tantos males y trastornos sufridos ¿seremos menos cautos en adoptar los medios más análogos para perpetuar la constitución que reestablecemos?». Aún más, cuando el jurista del Principado aseveró que el proceso constituyente de las Cortes gaditanas no era rupturista con la tradición constitucional hispánica: «No trataremos, Señor, como algunos se han persuadido, de formar una nueva Constitución, o hacer un nuevo pacto social; tratemos, sí, únicamente de restablecer nuestras leyes fundamentales, cuyo olvido ha acarreado a la Nación tantas desgracias». ${ }^{116}$

Así pues, Felipe Aner obvió la tradición constitucional de la antigua Corona de Aragón ${ }^{117}$ y legitimó exclusivamente su discurso mediante la evocación del historicismo castellano, fundamentándose esencialmente en la teoría de las leyes fundamentales, aquellas que eran irreformables o perpetuamente estables porque determinaban «las facultades de la $\mathrm{Na}$ ción, el modo legítimo de ejercerlas; se establece la forma de su Go-

115 DSC, n. ${ }^{\circ} 472,18$ de enero de 1812, p. 2651.

116 DSC, n. ${ }^{\circ} 472,18$ de enero de 1812, p. 2651.

117 Por ejemplo, véase Josep Maria Gay, «La legislació de la Cort i el control de la seva observança», L'Avenç, 74, 1984, pp. 68-71; y Joan Egea y Josep Maria Gay, «Eficàcia de les normes a la tradició jurídica catalana des de la baixa edat mitjana fins al decret de Nova Planta», Revista Jurídica de Cataluña, LXXVIII/2-3, 1979, pp. 7-52. 
bierno, y se hace la división de los tres poderes, base constitutiva de una Monarquía moderada», evitando la iniquidad absolutista, ya que según el diputado catalán si fuera «nula la separación de estas bases principales de la Constitución y de una Monarquía moderada» se causaría "por una consecuencia infalible, el desorden, la arbitrariedad y el despotismo». De hecho, para Aner la separación de poderes y la monarquía limitada dotada de un papel regulador y arbitral eran preceptos básicos para garantizar «la felicidad de la Nación»; más si cabe cuando una carta magna elaborada por unas Cortes reunidas «por el voto general de la Nación, y con amplios e ilimitados poderes para libertarla de la esclavitud que la amenazaba, y para asegurar de un modo duradero su independencia y libertad, creyeron que uno de los medios más eficaces, o quizá el único para lograr tan interesante objeto, seria el restablecer la Constitución de la Monarquía, cuya inobservancia y olvido debía considerarse el origen de todos los males». ${ }^{118}$ Asimismo, el abogado defendió la rigidez de la Pepa invocando el mandato parlamentario imperativo: «los diputados de las cortes actuales tenemos misión expresa para restablecer la constitución, sancionar su observancia». ${ }^{119}$

En definitiva, Aner solicitó que «las Cortes sucesivas ni deben tener las mismas facultades que las actuales, ni conviene que las tengan», ya que «ni la Constitución sería estable, ni sería fácil conservar inalterables los principios constitutivos de la Monarquía moderada». ${ }^{120}$ Efectivamente, tal y como requirió el parlamentario catalán, las Cortes gaditanas fijaron una serie de garantías para salvaguardar la inalterabilidad de la carta magna. ${ }^{121} \mathrm{El}$ artículo trescientos setenta y cinco $^{122}$ fue fundamental

118 DSC, n. ${ }^{\circ} 472,18$ de enero de 1812, p. 2652.

119 DSC, n. ${ }^{\circ} 472,18$ de enero de 1812, p. 2653.

120 DSC, n. ${ }^{\circ} 472,18$ de enero de 1812, p. 2652. En las exposiciones enviadas a la Junta Central en 1809 Ramón Lázaro de Dou aseveró que la mejor manera de asegurar la observancia de las leyes del reino era «la formación de Cortes por un estilo semejante al antiguo de Cataluña, jurándose por el rey la observancia de lo que en ella se establezca», más si cabe, cuando en el Principado se contaba con la figura del juez de agravios. Archivo de la Corona de Aragón, en adelante ACA, Fondo Guerra de la Independencia, Junta Superior, Caja 11, Ramón Lázaro de Dou, Cervera, 29 de agosto de 1809.

121 Javier Tajadura Tejada, «La defensa de la constitución en los orígenes del constitucionalismo hispánico: la «Hiperrigidez» constitucional», Revista de derecho político, 83, 2012, pp. 511-570; y Santiago Roura Gómez, La defensa de la constitución en la historia constitucional española. Rigidez y control de constitucionalidad en el constitucionalismo histórico español, Centro de Estudios Políticos y Constitucionales, Madrid, 1998.

122 DSC, n. ${ }^{\circ} 474,20$ de enero de 1812, p. 2671. 
porque reguló el sistema de modificaciones de la $P_{e p a^{123}}$. Los diputados doceañistas instauraron una rígida ${ }^{124}$ Constitución - ley eterna - para imposibilitar una inmediata variación. De hecho, la técnica jurídica de la rigidez constitucional era imprescindible para conferir estabilidad a las normas constitucionales y así poder consolidar un Estado de derecho. ${ }^{125}$ Aner había sido capaz de conjugar la distinción entre Cortes Constituyentes, Cortes ordinarias y Cortes de revisión de los constituyentes franceses de 1791 con la idea de que el Congreso sólo podía llevar a cabo la reforma o mejora de la Constitución histórica, pero sin alterar su esencia, esto es, sobre todo, su carácter monárquico tradicional, la confesionalidad católica del Estado y el estatus de sus estamentos, o sea, los principios básicos de las leyes fundamentales.

\section{Reflexión final}

Se convocaron unas Cortes Generales y Extraordinarias con la intención de recuperar la tradición histórica legislativa castellana - las leyes fundamentales (derechos de los súbditos, religión y forma de gobierno) - , pero en Cádiz, a raíz del decreto de 24 de septiembre de 1810 que otorgaba la soberanía a la nación, se inició un ex-novo, radical y liberal proceso constituyente que supuso, ni que sea sobre el papel, la derogación de la vieja estructura absolutista tardo-feudal. Desde el Principado se enviaron unas personalidades que atesoraban una imponente formación intelectual y académica - licenciados y doctores - , un elevado y notorio prestigio social y una acreditada experiencia profesional. El conocimiento histórico y filosófico, junto con la jurisprudencia - la pervivencia del derecho privado (particular), penal y procesal hizo necesario el conocimiento de las constituciones catalanas -, la retórica, la oratoria, el es-

123 «Hasta pasados ocho años después de hallarse puesta en práctica la Constitución en todas sus partes, no se podrá proponer alteración, adición ni reforma en ninguno de sus artículos». DSC, n. ${ }^{\circ} 471,17$ de enero de 1812, p. 2643.

${ }^{124} \mathrm{La}$ Constitución flexible es aquella que el parlamento la puede modificar como si se tratara de una simple ley ordinaria. Mientras que las constituciones rígidas solamente se reforman mediante un complejo procedimiento. Véase James Bryce, Constituciones flexibles y constituciones rígidas, Instituto de Estudios Políticos, Madrid, 1952.

125 Joaquín Varela Suances-Carpegna, La teoría del Estado en los orígenes del constitucionalismo hispánico (Las Cortes de Cádiz), Centro de Estudios Constitucionales, Madrid, 1983, pp. 306, 389-390 y 409. 
píritu crítico y la pluma se convirtieron en los instrumentos más útiles y necesarios para erigir un Estado legal de derecho o bien para refutar y paralizar cualquier iniciativa liberal.

Tanto serviles como reformadores catalanes se sirvieron del recurso discursivo y argumentativo que les proporcionaba el historicismo para sostener que los derechos y las libertades finieron gradualmente a partir de la Monarquía dual de los Reyes Católicos con la unión de la Corona de Castilla y la de Aragón ${ }^{126}$; perpetuándose un régimen despótico durante los reinados de las dinastías de los Áustrias y de los Bórbones - no es casual que, de manera significativa y sistemática, se omitieran las referencias a las Cortes catalanas o aragonesas del periodo moderno - que debía ser reemplazado mediante la recuperación y la reforma de la antigua Constitución de la Monarquía española - goticismo - y, particularmente, a partir del modelo político y jurídico pactista de la antigua Corona de Aragón - fueros aragoneses y valencianos y constituciones catalanas, abolidas en Cataluña por Felipe V mediante el Decreto de Nueva Planta de 1716-; por tanto, en Cádiz, los parlamentarios del Principado sostuvieron que no establecían un nuevo código legislativo, ni sus propuestas provenían, esencialmente para el caso liberal, de la Francia revolucionaria. No se trataba de inventar nada porque la revolución política gaditana no se presentó como discontinuidad sustancial con el pasado, sino únicamente de redescubrir unos principios que habían sido olvidados, y cuyo abandono había supuesto una inexorable decadencia. Así pues, en cierto sentido, a partir de una evidente exaltación romántica, la esplendorosa Historia medieval, aunque ésta fuese más mítica que real, y una Guerra de Independencia nacional - resistencia popular antinapoleónica equivalente a la reconquista de las libertades y derechos de la constitución histórica - se erigieron en las fuentes de la legitimidad del nuevo régimen constitucional. Ello no significa que podamos generalizar la valoración de los diputados catalanes como si a pesar del liberalismo de unos y el absolutismo de otros las diferencias entre ellos fuesen secundarias ya que coincidían en lo fundamental: el carácter pactista y consuetudinario, las constituciones catalanas, el régimen foral aragonés y la historia de la antigua Corona de Aragón como referentes, sino que debemos remarcar que únicamente

126 Jesús Lalinde ya evidenció que la integración vendría acompañada de un «retroceso» en la actividad foral. «Las libertades aragonesas», Revista Zaragoza, 49-50, 1975, pp. 89-118. 
los unió su acentuado patriotismo destinado a vencer al enemigo napoleónico y la utilización del pasado a partir de apropiaciones plurales de la historia, eso sí, para fines partidistas, o sea, exclusivamente para legitimar su propio y particular proyecto político, por otro lado, no siempre bien definido a título individual, ya que algunos vocales, como fue el caso de Aner, Capmany o Dou, librepensadores que podían manifestar ideas transversales, oscilaron en su adscripción ideológica de manera significativa dependiendo de la cuestión a debatir, explicitando la extraordinaria complejidad del proceso histórico constituyente gaditano. Asimismo, cabe recordar que en las Cortes gaditanas no existieron unos verdaderos partidos políticos. ${ }^{127}$ Quizás ya va siendo hora de enterrar anacronismos, maniqueísmos y dicotomías, mostrando en cambio una realidad más diversa, contradictoria y cambiante de la que bastantes estudios nos han querido mostrar.

Así pues, un historicismo basado en la doctrina contractual y en la tradición foral y constitucional de la antigua Corona de Aragón fue esgrimido por los parlamentarios conservadores catalanes, por ejemplo, para legitimar la soberanía compartida - rey y Cortes - , un congreso de representación estamental, el mantenimiento del régimen señorial o las prerrogativas de los eclesiásticos; y por los diputados liberales del Principado - eso sí, mediante un uso antihistórico, anacrónico y presentista de la historia - para validar la soberanía nacional, la separación de poderes, la supresión de los señoríos jurisdiccionales, la instauración del Consejo de Estado, la revocación del tormento o una rígida carta magna. De hecho, de manera especial, se debe resaltar la influencia de la jurisprudencia derivada de la práctica judicial de la Corona de Aragón en la protección de algunos derechos individuales; el origen goticista del Consejo de Estado como un contrapoder que vela por el procedimiento institucional en la elaboración de las leyes; y la vinculación de la representación eclesiástica en la tradición constitucional de la Corona de Aragón en función de su condición de propietarios, lo que vincula la representatividad posterior a esa condición. Del mismo modo, se debe remarcar que los parlamentarios catalanes reformistas equipararon las viejas instituciones - Diputación del

127 En las Cortes de Cádiz se difundió una imagen negativa del partido, equivalente a una facción que no pretendía el bien nacional o común, sino únicamente el de un grupo. Véase Ignacio Fernández Sarasola, La idea de partido en España: de la Ilustración a las Cortes de Cádiz (1783-1814), Biblioteca Virtual Miguel de Cervantes, Alicante, 2004. 
General o Generalidad - con las nuevas - diputación permanente - con el propósito de justificar la preservación de las futuras cortes y el cumplimiento de los designios legislativos. De hecho, los diputados procedentes de Cataluña consideraron que el despotismo gubernamental se podía mitigar mediante el ejemplo foral y constitucional de la antigua Corona de Aragón. Así que, las diferentes prácticas del modelo político pactista, el régimen foral aragonés, las constituciones catalanas y la propia historia de la Corona de Aragón se convirtieron en valiosos referentes para fijar y refrendar el extenso y a la par revolucionario articulado de un proceso constituyente doceañista que supuso el comienzo de una nueva etapa en la historia de España: la era constitucional, aquella que en el Principado catalán, por ejemplo, permitiría reinstaurar las libertades perdidas el 1714, a partir de la derogación de la Nueva Planta impuesta por Felipe V por justo derecho de conquista. 